\title{
Prolactin-Like Substance of Human Placenta
}

\author{
By \\ Makoto Kurosaki \\ From the Department of Obstetrics and Gynecology, Tohoku University \\ School of Medicine, Sendai; Director: Prof. K. Kushima
}

(Received for publication, June 5, 1961)

\section{INTRODUCTION}

Lactation is one of the most complicated physiological process carried out in living female mammals, and some hormones and several neural factors are mobilized in the process. The correlation between the placenta and lactation has been noted for a long time, as suggested by the avidity of mother mammals in eating up the expelled placenta. Halban ${ }^{1)}$ (1905), basing himself mainly on clinical observations, reported the existence of a substance in the ovary that stimulates the growth of the mammary glands but is not capable of causing lactation by itself, and predicted the discovery of some specific substance which stimulates the change of mammary gland by pregnancy in the syncytial cells of the placenta, thus foretelling the establishment of the endocrine nature of the placenta. Lactation, he says, begins with the expulsion of the placenta, that is, with the cessation of the endocrine secretion by it.

Since then, many works have been done on the mechanism of lactation and the lactogenic substances, but too many points of these problems are regrettably still in a shorud of darkness. The existence of some substance inciting lactation in the anterior pituitary lobe was proved by Stricker and Grüter') (1928), who succeeded in inducing lactation in pseudo-pregnant rabbits by injecting extract of the pituitary gland, and has been confirmed by many experimental studies since then. Riddle et al. ${ }^{3)}$ (1932) discovered that this lactogenic substance stimulates the crop gland of pigeon and entails crop lactation, and christend the substance "Prolactin". Ehrhardt") (1936) reported that this prolactin may be demonstrated in the human placenta in early pregnancy but not in mature placenta, while Ito $^{5}$ (1953) extracted the crop-reaction positive substance from human placenta and asserted that it is contained particularly rich in the mature placenta. Of course, there is a large camp of researchers who deny the existence of any lactogenic substance in the placenta. The present author also undertook

黒 唭 洵 
a study on this problem of lactogenic substance, using human placentae of various stages of pregnancy for experimental subcutaneous grafting near the crop of pigeons, and for testing the crop reaction following administration of their extraction in saline; similar tests were made with extracts prepared following some methods formulated by past authors for making pituitary extracts as well as a method of my own. Finally the chemical characteristics of the substance were also determined.

\section{METHODS}

1. Crop reaction with srude extracts

Samples of human placentae of various stages of pregnancy were treated as described in "Results", and the crop reaction was tested. Extracts were injected near the crop either intra- or hypodermally, or less frequently in the pectoral muscle once daily for 4 days with autopsy 24 hours after the last injection. In case of necessity, a portion of the crop-glands was cut out, fixed in $10 \%$ formalin solution and histologically examined after hematoxylin-eosin staining. The methods of experiments with rabbits and human subjects are given in the appropriate paragraphs in "Results".

2. Our new method for extraction

Next, the author made the experiments described below, utilizing the method applied by Yoshizaki' in his experiments for extracting the factor causing toxemia of pregnancy, which is useful in easily obtaining relatively large quantities of extracts. Fresh full-term placentae were washed, shredded, freed of blood with a press as far as possible, minced and mixed and stirred in physiological saline for extraction at low temperature. The precipitate (Fraction I) produced when the $\mathrm{pH}$ value of the extract was lowered to 4.2 was stirred in 3 mol saline at $\mathrm{pH}$ 7.0 , the $\mathrm{pH}$ value was again lowered to 4.2 , and from the precipitate produced, Protein I was isolated. The supernatant remaining after separating Fraction I above was adjusted to $\mathrm{pH} 7.0$, totally saturated with ammonium sulfate, the precipitate produced hereby was throughly dialysed in running water and the precipitate produced at $\mathrm{pH} 5.8$ (Fraction II) was processed, Protein II being obtained. The supernatant after elimination of Fraction II was repeatedly mixed with $\mathrm{HCl}$ to lower the $\mathrm{pH}$ value to 2.0 and with $\mathrm{Ba}(\mathrm{OH})_{2}$ to raise it to 9.0 , for eliminating nucleic acid, freed of $\mathrm{Ba}$ with $\mathrm{H}_{2} \mathrm{SO}_{4}$ mixed with alcohol to $15 \%$, and Protein III was obtained from the precipitate produced (Fraction III). The recovery rate was $40 \mathrm{mg}$. each of Proteins I and II and $20 \mathrm{mg}$. of Protein III.

\section{RESULTS}

1. Crop reaction with crude extracts

1) Crop reaction after subcutaneous transplantation of human placental grafts 
Fresh decidua, chorion or entire placenta was thoroughly rinsed in water, to remove all blood, repeatedly pressed between filter papers to draw off water, weighed and grafted beneath the skin near the crop of pigeons, and the reaction was evaluated on the 5th day. For control tests, uterine muscles or subcutaneous fat was similarly grafted. Implanting of a placental sample of any stage of pregnancy caused crop reaction similar to that at the time of incubation and nursing youngs, consisting in hyperemia, thickening and opacity of the mucous membrane. In the control tests of grafting uterine muscles and subcutaneous fat too, capsules were formed around the graft by aggregated connective tissue and the crop's mucous membrane was thickened and turned. opaque.

2) Crop reaction after injection of placental extract in saline

Fresh samples were mixed with double volume of physiological saline, left standing for a night, centrifuged, and the supernatant was kept in ice-box. After daily injection of this extract subcutaneously near the crop for 4 days, the reaction was evaluated on the 5th day. The extract from placenta of the early stage caused slight vascular dilatation in the mucous membrane, but that from full-term placenta caused no reaction.

3) Crop reaction after administration of other extracts

For preparing the extract, placentae sampled at full-term delivery were subjected to the process suggested by Bonsnes $\left.{ }^{6}\right), \mathrm{Li}^{71}$ and Lyons ${ }^{8}$. With some fractions, mild congestion and thickening were caused in the mucous membrane, but in any case, the reaction was too weak to be called positive.

2. Experiments with extracts by our new method

1) Crop reaction in pigeons

a) After intradermal injection

When any of the fractions above was injected into the skin over the crop, the result was always positive. The per pigeon unit equivalent was $2 \mathrm{mg}$. with Protein I, $1 \mathrm{mg}$. with Protein II and $1 / 2 \mathrm{mg}$. with Protein III, that is, the pigeon. unit per $1 \mathrm{mg}$. of fraction was $1 / 2$ with Protein I, 1 with Protein II and 2 with Protein III (TABLE I).

TABLE I. Crop-Reaction after Intradermal Injection

\begin{tabular}{|c|c|c|c|c|c|}
\hline No. of pigeon & Body weight & Extract & Dose (mg.) & Response & $\underset{\text { (mg.) }}{\text { Pigeon unit }}$ \\
\hline $\begin{array}{l}1 \\
2 \\
3\end{array}$ & $\begin{array}{l}290 \\
340 \\
310\end{array}$ & Protein I & $\begin{array}{l}1 \\
2 \\
4\end{array}$ & $\begin{array}{l}\bar{t} \\
+\end{array}$ & $1 / 2$ \\
\hline $\begin{array}{l}4 \\
5 \\
6\end{array}$ & $\begin{array}{l}320 \\
340 \\
350\end{array}$ & Protein II & $\begin{array}{c}1 / 2 \\
1 \\
2\end{array}$ & $\begin{array}{l} \pm \\
+ \\
+\end{array}$ & 1 \\
\hline $\begin{array}{l}7 \\
8 \\
9\end{array}$ & $\begin{array}{l}310 \\
285 \\
300\end{array}$ & Protein III & $\begin{array}{c}1 / 4 \\
1 / 2 \\
1\end{array}$ & $\begin{array}{l} \pm \\
+ \\
+\end{array}$ & 2 \\
\hline
\end{tabular}


b) After intramuscular injection

As by the intradermal injection method the possibility of non-specific inflammatory reaction due to impurities is not excluded, the crop reaction was tested also by intramuscular injection of the same fractions in the pectoral muscles. Positive results were obtained after injection of $20 \mathrm{mg}$. of Protein I and $10 \mathrm{mg}$. of Protein II or III. The epithelium of the crop mucosa formed large folds, many downgrowths of germinative zone were found and the connective tissue layer forming the tunica propria was found thinned down. Some of the enlarged folds tended to form a plateau by mutual fusion (Figs. 1, 2, 3 and 4).

2) Experiments with rabbits

a) By Meites and Turner's ${ }^{10}$ ) method

Rabbits on the 15th day of pseudopregnancy were injected with the tested protein fractions in the lactiferous tubuli under ether anesthesia, and sacrificed 5 days thereafter for testing the milk production. As shown in TABLE II, milk could be actually pressed out in one case only after $5 \mathrm{mg}$. of Protein II. After Protein II, the lactiferous tubules were strongly proliferated, the terminal apparatus were aggregated into glandular lobules and fat drops were found in the lumina of the terminal alveoli (Figs. 5, 6 and 7).

TABLE II. Meites and Turner's Method

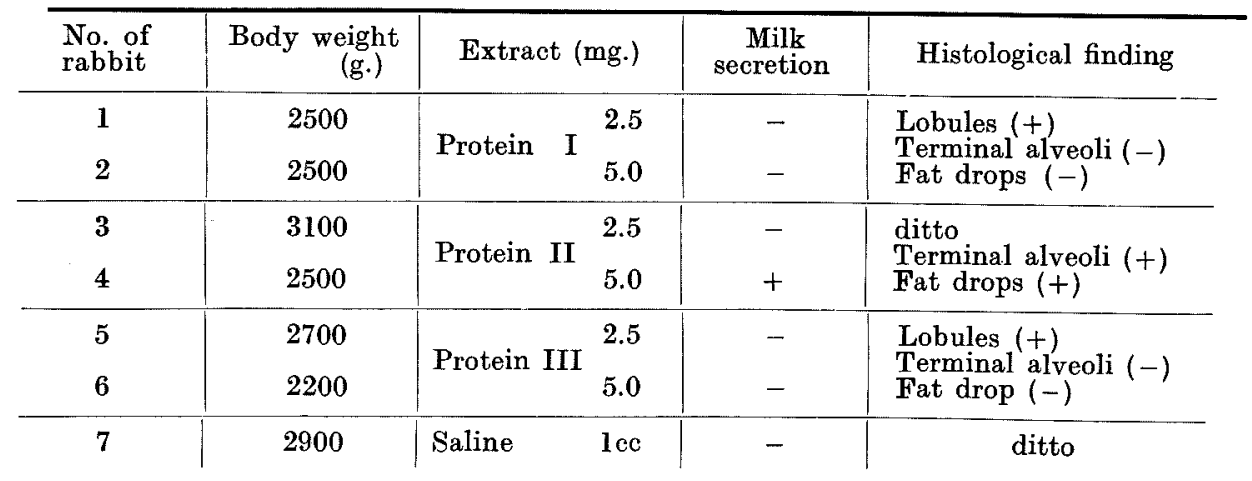

b) Experiments with rabbits after throwing

Adult rabbits of $2-3 \mathrm{~kg}$. body weight and having experiences of throwing but with their lactation completely suspended after lapse of more than one month after the last milking were injected with the above protein fractions once a day for a week, and the effect on their mammary glands and milk production was studied. As shown in TABLE III, all the fractions were found to cause lactation, for after Protein I milk could be pressed out from the 5th day, after Protein II from the third day and after Protein III from the second day onwards, and even after completion of a series of injection for a week, milking remained possible for 4 days, 6 days and 4 days with each case, respectively. In these cases, histological 
Table III. Experiments with

\begin{tabular}{c|c|c|c|}
\hline No. of rabbit & Body weight (kg.) & Extract (mg.) & \\
\hline 1 & 2.8 & Protein I 35 & \\
\hline 2 & 3.1 & Protein II 35 & \\
\hline 3 & 3.0 & Portein III 35 & \\
\hline 4 & 2.9 & Saline 7cc &
\end{tabular}

examination revealed high proliferation of the terminal alveoli and presence of numerous fat drops (Figs. 8, 9 and 10).

3) Effect on lactation in human subjects

a) Method of measuring lactation

The total weight of the suckling in draper just before and after sucking was weighted under precisely the same condition and the difference in weight was taken to represent the quantity of milk ingested in one sucking. At every lactation, the process was repeated and the total daily quantity was computed.

b) Application of fractions

Puerperae free from notable complicating diseases were indiscriminately injected with 200 pigeon units each of the fractions for 5 consecutive days, regardless of the growth of their mammary glands, etc. and the quantity of daily lactation was measured for comparative study. At the injection, no side-effect could be observed, except for slight pain and reddening at the site.

c) Effect of the fractions

As controls, the mean daily quantity of lactation of 100 puerperae without experience of lactogeogues and free from excessive disturbance of lactation due to complications was computed down to the 6th day of puerperium. The results, as shown in TABLE IV, showed that all the fractions were more or less effective in the stimulation of lactation, though it must be confessed that the tested cases were regrettably few. On the 6 th day of puerperium, lactation was increased by $13 \%$ after Protein I, by $37 \%$ after Protein II and by $12 \%$ after Protein III.

4) Chemical properties of the extracts

a) Test-tube tests

The results are shown in TABLE $V$.

b) Paper chromatography of the amino acids in the proteins

Primary development was effected with butanol plus glacial acetic acid plus water in the ratio of $4: 1: 2$, secondary development with phenol plus water in 
Rabbits after Throwing

\begin{tabular}{|c|c|c|c|c|c|c|c|c|c|c|c|c|c|c|}
\hline Date & 1 & 2 & 3 & 4 & 5 & 6 & 7 & 8 & 9 & 10 & 11 & 12 & 13 & 14 \\
\hline Injection & & & & & & & & & & & & & & \\
\hline Milk secretion & - & - & - & - & \pm & + & + & + & + & \pm & \pm & - & - & - \\
\hline Injection & & & & & & & & & & & & & & \\
\hline Milk secretion & - & - & \pm & + & $H$ & H & $H$ & H & + & + & + & + & \pm & - \\
\hline Injection & 5 & $\longrightarrow$ & & & & & 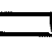 & & & & & & & \\
\hline Milk secretion & - & \pm & + & H & H & $H$ & H & + & \pm & \pm & + & - & - & - \\
\hline Injection & & & & & & & & & & & & & & \\
\hline Milk secretion & - & - & - & - & - & - & - & - & - & - & - & - & - & - \\
\hline
\end{tabular}

TABLE IV. Effect on Lactation in Human Subjects

\begin{tabular}{c|r|rrrrrr}
\hline Extract & Date & 1 & 2 & 3 & 4 & 5 & 6 \\
\hline Control & 100 & 13 & 68 & 145 & 221 & 279 & $317(\mathrm{cc})$ \\
\hline \multirow{2}{*}{ Protein I } & \multirow{2}{*}{10} & 13 & 89 & 171 & 216 & 319 & $358(\mathrm{cc})$ \\
\cline { 2 - 8 } & \multirow{2}{*}{ Protein II } & 100 & 131 & 117 & 98 & 114 & $113(\%)$ \\
\hline \multirow{2}{*}{ Protein III } & 10 & 4 & 115 & 206 & 354 & 373 & $434(\mathrm{cc})$ \\
\hline & 10 & 13 & 57 & 101 & 229 & 296 & $356(\mathrm{cc})$ \\
\hline
\end{tabular}

TaBle V. Results of Test-tube Tests

\begin{tabular}{l|c|c|c}
\multicolumn{1}{c|}{ Tests } & Protein I & Protein II & Protein III \\
\hline Biuret & H & H & + + \\
Molisch & - & - & - \\
Goldschrniedt & - & - & - \\
Neuberg-Saneyoshi & - & - & - \\
Test for phosphorus & - & - & - \\
Dische for deoxypentose & - & + & + \\
Millon & + & - & + \\
Hopkins-Cole & - & + & + \\
Sakaguchi & + & &
\end{tabular}

the ratio of $4: 1$, temperature $: 25 \pm 1^{\circ} \mathrm{C}$, reagent : $0.1 \%$ ninhydrin. The chromatograms of the proteins showed in common spots at the positions corresponding to aspartic and glutamic acids, serine, glycine, threonine, alanine, tyrosine, leucine and/or isoleucine, valine and/or methionine, proline, lysine, histidine and arginine. 
Those of Protein III showed spots of phenylalanine and of hexosamine in addition.

c) Electrophoresis

Proteins I, II and III were examined in $0.5 \%$ water solution, phosphate buffer, $\mathrm{pH} 7.7, \mathrm{I} 0.2,10 \mathrm{~mA}$. All the patterns showed one sharp boundary.

d) Solubility and precipitablity of the preparations

The preparations were insoluble in glacial acetic acid. Their watery solutions precipitated on addition of lead acetate, cupric chloride and trichloroacetic acid and on saturation with ammonium sulfate, but did not on addition of bariumacetate and -chloride.

\section{DISCUSSION}

It was Halban'1) (1905) that first discussed placenta in connection with endocrine secretion. He asserted that the growth of the mammary glands in gravidae may be attributed to the agency of placental action, basing himself on clinical observations, and that the milk secretion can be explained as due to a reparation process of the milk glands resulting from the cessation of the stimulation for growth from the placenta, but he did not think of any positive lactogenic function of the placenta. Since then, the literature which is mainly concerned. with the placental function in the direction of stimulation of mammary growth and milk secretion has been very copious. Following Halban, Schäfer ${ }^{12)}$, Frankel ${ }^{13\}}$ and Nelson ${ }^{14)}$ opined that the placenta had inhibitory action on lactation, while among others Biedl' ${ }^{15)}$, Frank ${ }^{16)}$, Litt ${ }^{17)}$, Grüter and Stricker ${ }^{18)}$ may be mentioned as denying almost any effect of the placenta on it. Kawaida ${ }^{19}$, Fellner $^{20)}$, Hermann ${ }^{21}$, Takahashi ${ }^{21}$, Miyagawa ${ }^{23)}$ and $\mathrm{Kita}^{24)}$ belong to the camp that acknowledge some effect on the growth of the mammary glands but do not acknowledge any effect sufficing to cause actual lactation, or going at most to cause secretion of colostrum, in the placenta, while Aschner and Grigoriu ${ }^{25}$ ) asserted that injection with chyle and water or alcohol extraction of the placenta causes growth of the mammary glands and lactation, and $\mathrm{Basch}^{26)}$, Mayer ${ }^{27}$,

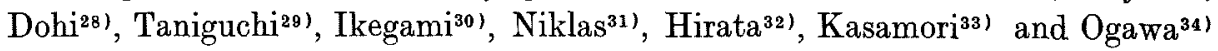
have arrived to quite similar conclusions.

The present author found that subcutaneous injection of the tested fractions of protein in rabbits that have already lost power of lactation after the last throwing caused resumption of lactation.

Since Riddle et al. perfected the method of assaying lactogenic hormones by crop reaction in pigeons, many reports have appeared on the crop reaction after placental substances. Keller ${ }^{35}$ ) found positive crop reaction following transplantation of placenta to pigeons, and says that about one-third of mature placentae contains a lactogenic substance, and this substance is found especially frequently in immature placentae, in hydatidiform moles, and chorionepithelioma. 
Ehrhardt succeeded in proving the existence of prolactin in the placenta, in a large content the younger the placenta; he found relatively large quantity of prolactin in the extract from hydatidiform moles, and says that he could obtain a hormone of 10-20 pigeon units from $1 \mathrm{cc}$ of the above substance. Fujii ${ }^{36)}$ could not find positive crop reaction following intramuscular injection of acidic and alkaline placental extracts of any stage of pregnancy, but could prove prolactin in the placenta of rats only. Ray et al. ${ }^{37)}$ report that a 12 day old placenta of a rat is equivalent to $0.01 \mathrm{mg}$. of hypophyseal prolaction in the effect of stimulating lactation and to about $2 \mathrm{mg}$. of it in the effect of stimulating formation of corpora lutea. Averill ${ }^{38)}$, Astwood ${ }^{39)}$ and Lyons also acknowledge the effect of rat placenta extract in causing positive crop reaction. Mayer and Canivenc ${ }^{40}$ ) found the stimulating effect on luteal bodies, the growth of mammary glands and even the secretion of milk stimulated after auto-implantation of trophoblast from the placenta of rats, and ascribes stronger effects in these three functions but a weaker effect in stimulating crop reaction to the factor in these cells, in comparison with the respective effects of hypophyseal prolactin. Akasu and Otani ${ }^{41}$ and. $\mathrm{Akasu}^{42}$ ) report that the chorionic gonadotropin extracted from the human placenta was experimentally and clinically confirmed to have a lactogenic action on the mammary glands of multiparae or nulliparae pretreated with the same hormone; they say that this substance is similar to prolactin in its action on the luteal bodies, but differs from it in causing negative crop reaction. Akasu et al. found this hormone was very effective in clinical application, Oda ${ }^{43)}$ admits some lactogenic effect of it, but Matsumoto et al.44) deny a stimulating effect on milk secretion in it. Iida ${ }^{45}$ et al. report that administration of chorionic gonadotropin to patients with deficient lactation had little effect, and if any, only a transient effect. But Nakamura ${ }^{46)}$ acknowledged the efficacy of this hormone and recommended it in treating oligogalactic puerperae. More recently, Ito succeeded in extracting a substance effective in causing thickening of the crop mucosa, similar to that after prolactin, from human placentae, especially, mature human placentae, and by isoelectric fractionation, obtained 3 different precipitates of $\mathrm{pH} 6.5,6.0$ and 5.5, respectively from this substance. Upon making crop reaction with these fraction, he found the $\mathrm{pH} 5.5$ fraction most effective. By improving his method of extraction, he obtained an even more effective fraction by water extraction and ammonium-sulfate fractionating, and reported that this substance was so effective as to cause a conspicuous thickening of the epithelial layer and a marked growth in size and number of lactic fat drops in the crop-milk. This amplification of fat drops was rather perceptible in 48 hrs. after single dosage of the substance already, rose parallel with the increase of the dosage and showed little individual difference, so that this augmentation of fat drops can be useful as index in purifying the prolactin-like substance in the human placenta. His method of extraction is very similar to the one fol- 
lowed by the present author, and the effect of the extracts in causing crop reaction is also similar. In the next place, upon clinical application of my extract, the extract proved sometimes very effective but sometimes nearly of no effect in increasing lactation. Such contradictory results, however, may be accepted as rather natural, when we recall that the mechanism of lactation is so complicated and is subject to the influence of many factors concerning mental conditions, development of the mammary glands, the nutrition, etc. of the puerpera. In the next place, we face the question why physiological lactation is inhibited during pregnancy and begins as soon as delivery is over. Akasu ${ }^{47}$ says that the gonadotropin in the placenta is all used up in elaborating progesterone therein, so that little is left available for instigating milk production, and also the mammary glands are subject to the strong influence of estrogen-progesterone during pregnancy for stimulating growth of the glands, so that the influence of gonadotropin, if even available, cannot interfere. The effect of my extract also may be partly subject to the same action mechanism.

In the last place, it must be mentioned that some reports on the chemical identity of such placental substances are available. Since Fellner ${ }^{20)}$ (1913) first reported his success in isolating from the placenta the effective substance acting upon the mammary glands and opined that the substance may be a lipoid, there were reports by Hermann who presumed it to be a cholesterine derivative, by Dohi and Ikegami who saw a lipoid substance in it, by Taniguchi who says that placental phosphatide preferentially stimulates the growth of mammary glands and the placental protein decomposates the secretion of milk. More recently, many authors have presumably identified it with trophoblast hormone, prolactin and such protein hormones. The present author studied the chemical properties of the placental extract and ascertained that the substance consisted in a protein resembling prolactin.

\section{SUMMARY}

1. Implantation of placentae of several stages of pregnancy beneath the skin near the crop of pigeons always caused considerable hyperemia, thickening and opacity of the mucous membrane.

2. Placental extract in saline caused negative crop reaction.

3. Placental extracts prepared by Bonsens and White's method, Li's method and Lyon's method always caused negative crop reaction.

4. The three extracts prepared by our method from full-term human placentae with the isoelectric point at $\mathrm{pH} 5.0, \mathrm{pH} 5.8$ and $\mathrm{pH} 6.0$ caused always positive crop reaction, $1 \mathrm{mg}$. of them being equivalent to $1 / 2,1$ and 2 pigeon units, respectively. Positive reaction also followed intramuscular injection of $20 \mathrm{mg}$. of $\mathrm{pH} 5.0$ and $\mathrm{pH} 5.9$ fractions and $10 \mathrm{mg}$. of $\mathrm{pH} 6.0$ fraction.

5. Only the $\mathrm{pH} 5.8$ fraction caused lactation upon injection into the 
lactiferous tubules of pseudo-pregnant rabbits.

6. When injected in post-puerperal rabbits with completely stopped lactation, all the fractions caused resumption of lactation.

7. When injected in puerperal women, all the fractions caused the increase of secreted milk over that in the non-treated controls. No side-effect of the administration was perceptible.

8. The chemical properties of the fractions were determined. The results pointed to the inference that it consisted in a prolactin-like protein.

\section{Acknowledǵments}

In conclusion, the author hastens to express heartly thanks to Prof. K. Kushima for his unfailing kindness in supervising my study and revising this report. My thanks are due also to Dr. H. Yoshizaki for his valuable suggestions and to Dr. S. Matsushima of Teikoku Zoki Pharmacy for his kind assistance in carrying out my experiments.

\section{References}

1) Halban, J., Arch. Gynäk., 1905, 75, 353.

2) Stricker, P. \& Grüter, F., Compt. Rend. Soc. Biol., 1928, 99, 1978.

3) Riddle, O., Bates, R. W., \& Dykshorn, S. W., Am. J. Physiol., 1933, 105, 191.

4) Ehrhardt, K., Münch. Med. Wschr., 1936, 29, 1163.

5) Ito, Y., Yakugaku Zassi (Jap.), 1943, 73, 1.

6) Bosnes, R. W. \& White, A., Endocrinol., 1940, 26, 990.

7) Li, C. H., Lyons, W. R. \& Evans, H. M., J. Am. Chem. Soc., 1940, 62, 2925.

8) Lyons, W. R. \& Page, E., Proc. Soc. Exp. Biol. \& Med., 1934, 32, 1049.

9) Yosizaki, H., Tohoku J. Exper. Med., 1957, 66, 333.

10) Meites, J. \& Turner, C. W., Am. J. Physiol., 1947, 150, 394.

11) Halban, J., Arch. Gynäk., 1905, 75, 353.

12) Schäfer, E. A., Münch. Med. Wschr., 1913, 27, 1925.

13) Frankel, O., Am. J. Obst. \& Gynec., 1923, 6, 399.

14) Nelson, O. W., Ber. Ges. Gynäk. Geburtsh., 1933, 25, 331.

15) Biedl, A. \& Königstein, E., Zeitshr. Exper. Path. Ther., 1911, 8, 358.

16) Frank, R. T., Zbl. Gynäk., 1912, 41, 377.

17) Litt, S., Am. J. Obstet. \& Gynec, 1933, 26, 37.

18) Grüter, F. \& Stricker, P., Klin. Wschr., 1929, 50, 2322.

19) Kawaida, G., Nippon Fujinka Gakkai Zassi (Jap.), 1912, 7, 283.

20) Fellner, O., Arch. Gynäk., 1913, 100, 641.

21) Hermann, E., Monatschr. Geburtsh., 1915, 41, 1.

22) Takahashi, T., Okayama Igaku Zassi (Jap.), 1922, 395, 733.

23) Miyagawa, Y. \& Saito, K., Nippon Iji Shinpo (Jap.), 1928, 282.

24) Kita, Y., Nippon Fujinka Gakkai Zassi (Jap.), 1933, $28,6$.

25) Aschner, B. \& Grigoriu, C., Areh. Gynäk., 1911, 94, 766.

26) Basch, K., Arch. Gynäk., 1912, 96, 204.

27) Mayer, G., Zbl., Gynäk., 1912, 41, 1355.

28) Dohi, M., Nippon Fujinka Gakkai Zassi (Jap.), 1919, 15, 398.

29) Taniguci, Y., Nippon Fujinka Gakkai Zassi (Jap.), 1923, 18, 56.

30) Ikegami, G., Nissin Igaku (Jap.), 1921, 11, 4.

31) Niklas, F., Monatschr. Geb. Gyn., 1913, 38, 60.

32) Hirata, Y., Hokkaido Igakukai Zassi (Jap.), 1928, 6, 513. 
33) Kasamori, S., Fujimoto, K., Takeda, F. \& Komai, M., Nippon Fujinka Gakkai Zassi (Jap.), 1934, 29, 478.

34) Ogawa, K., Nippon Naibunpi Gakkai Zassi (Jap.), 1936, 12, 1051.

35) Keller, E., Zbl. Gynäk., 1939, 63, 43.

36) Fujii, K. Nippon Fujinka Gakkai Zassi (Jap.), 1938, 33, 323.

37) Ray, W., Averill, C., Lyons, R. \& Johnson, E., Endocrinol., 1955. 56, 359.

38) Averill, C., Ray, W. \& Lyons, R., Proc. Soc. Exp. Biol. \& Med., 1950, 75, 3.

39) Astwood, E. B. \& Greep, R. O., Proc. Soc. Exp. Biol. \& Med., 1938, 38, 713.

40) Mayer, G. \& Canivenc, R., Compt. Rend. Soc. Biol., 1950, 144, 410.

41) Akasu, F. \& Ooya, J., Rinsho Fujinka Sanka (Jap.), 1951, 5, 439.

42) Akasu, F., Tiryo (Jap.), 1960, 42, 1933.

43) Oda, A., Sanfujinka no Sekai (Jap.), 1953, 6, 644.

44) Matsumoto, S. \& Niimura, T., Rinsho Fujinka Sanka (Jap.), 1952, 6, 332.

45) Iida, M., Nippon Sanka Fujinka Gakkai Zassi (Jap.), 1951, 3, 199.

46) Nakamura, K., Nippon Sanka. Fujinka Gakkai Chugoku Sikoku Rengosi (Jap.). $1956,5,61$.

47) Akasu, F., Taiban no Naibunpi (Jap.), Nankodo Press, Tokyo-Kyoto, 1958. 


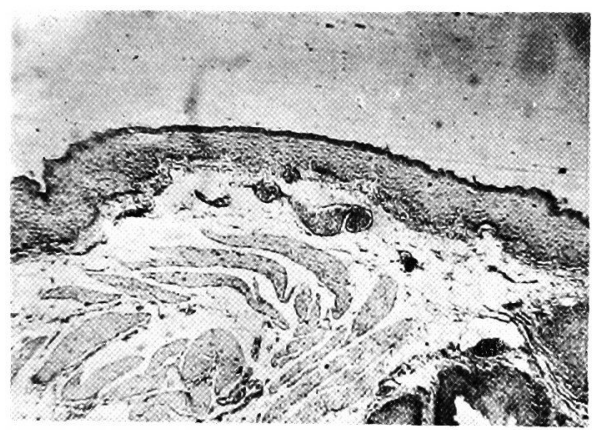

Fig. 1. Section of normal crop sac membrane.

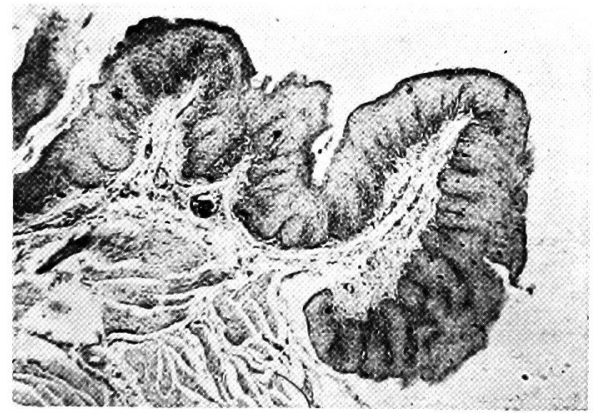

Fig. 2. After intramuscular injection of $20 \mathrm{mg}$. of Protein I. Note the enlarged folds bearing numerous short downgrowths.

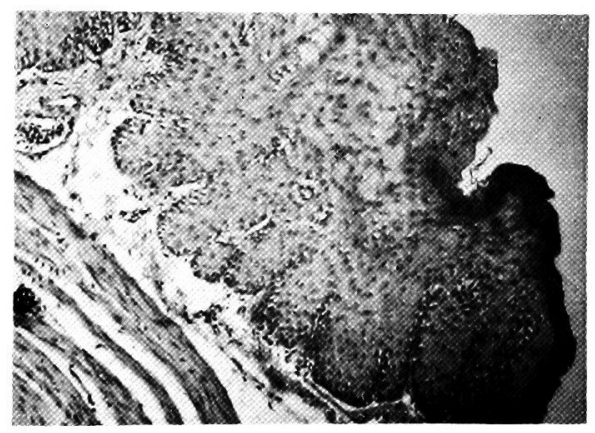

Fig. 3. After intramuscular injection of $10 \mathrm{mg}$. of Protein II. Note the enlarged folds of thickened mucosa with epithelial downgrowths. 


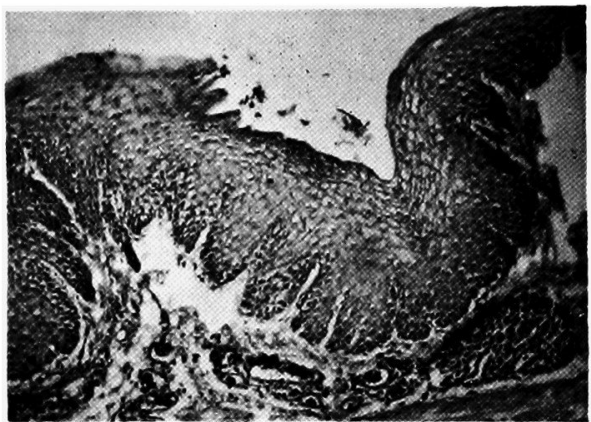

Fig. 4. After intramuscular injection of $10 \mathrm{mg}$. of Protein III. Note that the enlarged folds bearing characteristic downgrowths of cells are tending to fuse along the adjoining surface.

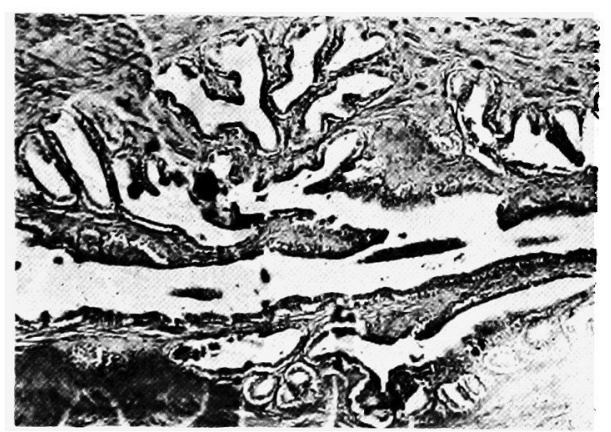

Fig. 5. Mammay gland after injection of Protein I $5 \mathrm{mg}$. in the milk duct.

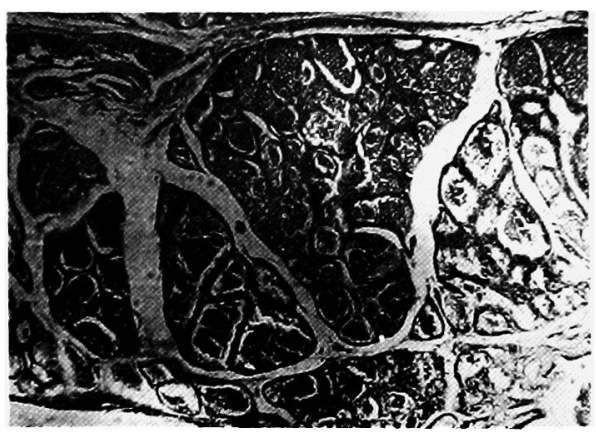

Fig. 6. Mammary gland after injection of Protein II $5 \mathrm{mg}$. in the milk duct. 


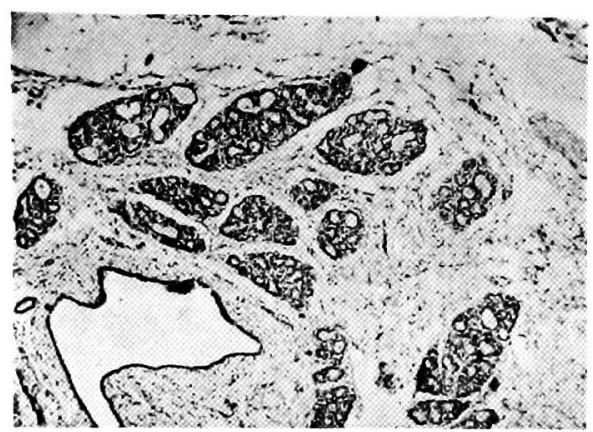

Fig. 7. Mammary gland after injection of Protein III $5 \mathrm{mg}$. in the milk duct.

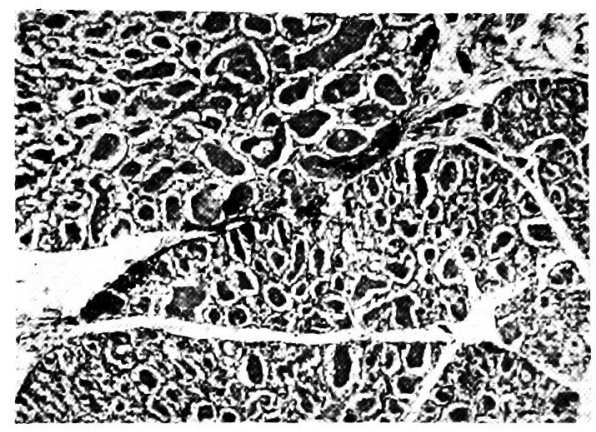

Fig. 8. Mammary gland after throwing injected with Protein I $35 \mathrm{mg}$.

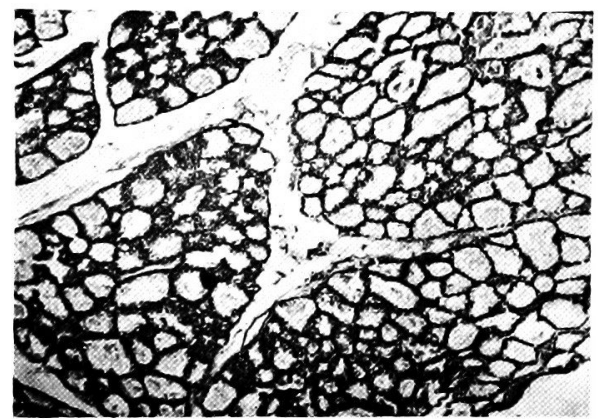

Fig. 9. Mammary gland after throwing injected with Protein II $35 \mathrm{mg}$ 


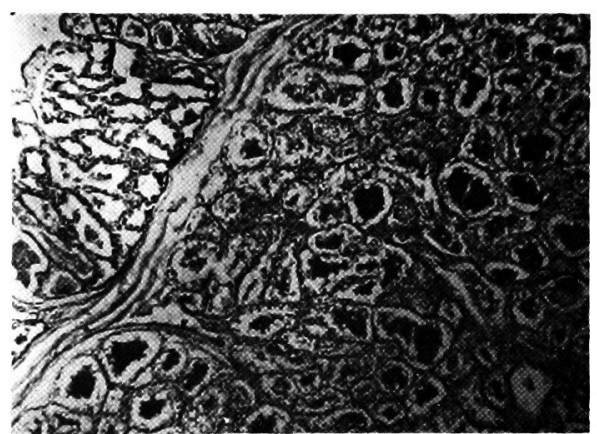

Fig. 10. Mammary gland after throwing injected with Protein III $35 \mathrm{mg}$ 